\title{
Effects of Feeding Vitamin A and Lactoferrin on Epithelium of Lymphoid Tissues of Intestine of Neonatal Calves*
}

\author{
T. Schottstedt, C. Muri, C. Morel, C. Philipona, H. M. Hammon, and J. W. Blum \\ Division of Nutrition and Physiology, Institute of Animal Genetics, Nutrition and Housing, \\ Vetsuisse Faculty, University of Berne, $\mathrm{CH}-3012$ Berne, Switzerland
}

\begin{abstract}
Circulating levels of vitamin A (retinol) and lactoferrin (Lf) are low in calves at birth. Bovine colostrum contains relatively high amounts of vitamin A and Lf, and both substances are intestinally absorbed by neonatal calves. There is evidence that these compounds interact with insulin-like growth factor binding proteins and thus influence the status and effects of insulin-like growth factor. The hypothesis was therefore tested that vitamin A and Lf influence epithelial growth, development, and absorptive capacity of the small and large intestine and modulate intestinal immune tissues (Peyer's patches; PP). Four groups of calves ( $n=7$ per group) were fed a milk-based formula with or without vitamin A and (or) Lf. Group F received formula $(\mathrm{F})$ only; group $\mathrm{F}_{\mathrm{A}}$ was fed $\mathrm{F}$ supplemented with vitamin $A$; group $F_{L}$ was fed $F$ supplemented with $\mathrm{Lf}$, and group $\mathrm{F}_{\mathrm{AL}}$ received $\mathrm{F}$ plus vitamin A plus Lf. An additional group of calves (group $\mathrm{C} ; \mathrm{n}=$ 7) served as positive control and was fed colostrum (C) from pooled milk obtained on d 1, 2, and 3 of lactation. Amounts of nutritive components in formula and colostrum were similar. Blood samples were taken to measure vitamin A and Lf, and plasma xylose (added on $\mathrm{d} 4$ to feeds) was measured postprandially for $8 \mathrm{~h}$ as a marker of intestinal absorptive capacity. Plasma vitamin A was low at birth and further decreased in groups $F$ and $F_{L}$, but increased in groups $F_{A}, F_{A L}$, and C. Plasma Lf was low at birth and transiently increased up to $4 \mathrm{~h}$ after the first meal in group C. Xylose absorption was higher in group $\mathrm{C}$ than in other groups. Incorporation of 5-bromo-2'-deoxyuridine into DNA (as a measure of cell proliferation rate) was enhanced in intestinal crypts in groups $\mathrm{F}$ and $\mathrm{F}_{\mathrm{L}}$ at all intestinal sites. Ileum villus heights of groups $\mathrm{F}$ and $\mathrm{F}_{\mathrm{L}}$ were smaller than of groups $\mathrm{F}_{\mathrm{A}}$ and $\mathrm{F}_{\mathrm{AL}}$. Villus height to
\end{abstract}

Received June 11, 2004.

Accepted October 7, 2004.

Corresponding author: J. W. Blum; e-mail: juerg.blum@itz. unibe.ch.

*Part of a thesis of T. Schottstedt for DMV, accepted by Vetsuisse Faculty, University of Berne, Switzerland, June 2004. crypt depth ratios were smaller in F-fed groups (especially in groups $\mathrm{F}$ and $\mathrm{F}_{\mathrm{L}}$ ) than in $\mathrm{C}$-fed calves in the duodenum and jejunum. Incorporation of 5-bromo-2'deoxyuridine into colon crypt cells of group $\mathrm{F}$ was greater than in groups $\mathrm{F}_{\mathrm{L}}$ and $\mathrm{F}_{\mathrm{A}}$. Sizes of follicles of $\mathrm{PP}$ in the ileum were greater in group $\mathrm{F}_{\mathrm{A}}$ than in group F. In the ileum, vitamin A and Lf tended to interact with PP size. In conclusion, feed supplementation of vitamin $\mathrm{A}$ and Lf influenced growth of the ileum and colon. Interactions were observed between vitamin A and Lf on epithelial cell maturation, villus growth, and size of follicles in PP of neonatal calves.

(Key words: intestine, lactoferrin, vitamin A, neonatal calf)

Abbreviation key: BrdU = 5-bromo-2'-deoxyuridine, $\mathbf{C}=$ colostrum, $\mathbf{F}=$ formula, $\mathbf{F}_{\mathbf{A}}=$ formula + vitamin $\mathrm{A}$, $\mathbf{F}_{\mathrm{AL}}=$ formula + vitamin A + lactoferrin, $\mathbf{F}_{\mathbf{L}}=$ formula + lactoferrin, GIT = gastrointestinal tract, $\mathbf{L f}=$ lactoferrin, $\mathbf{P P}=$ Peyer's patches, $\mathbf{T U N E L}=$ terminal deoxynucleotidyl transferase (TdT3')-mediated X-dUTP nick end labeling.

\section{INTRODUCTION}

In addition to nutrients, bovine colostrum $(\mathbf{C})$ also delivers to the newborn calf nonnutrient factors (Ig and bioactive substances such as hormones, growth factors, and cytokines), lactocytes, erythyrocytes, and lymphocytes (Blum and Baumrucker, 2002). Concentrations of IGF, insulin, lactoferrin (Lf), and vitamin A (retinol) are high in bovine colostrum at the first milking (Blum and Baumrucker, 2002). Ingestion of $\mathrm{C}$ in the neonatal calf is followed by changes in the development and functions of the gastrointestinal tract (GIT), causing metabolic and endocrine changes (Blum and Baumrucker, 2002) and influencing immune systems of the GIT (David et al., 2003; Norrman et al., 2003). The importance of growth hormone, IGF, IGF binding proteins, and insulin, ingested with $\mathrm{C}$ or endogenously produced, in the neonatal calf and in the GIT has been the subject of intensive research during recent years (Blum and Baumrucker, 2002). Sufficient amounts of vitamin A and of its bioactive metabolites 
(retinoic acid) are essential for the maintenance of physiological functions as well as for epithelial cell integrity, cell proliferation, cell differentiation, apoptosis, general development, and immune functions (Blomhoff et al., 1992; Woodward et al., 1996; Elitsur et al., 1997). The newborn calf is characterized by insufficient hepatic vitamin $\mathrm{A}$ reserves and low plasma vitamin A concentrations, and it requires ingestion of high amounts of vitamin A with colostrum immediately after birth to avoid vitamin A deficiency disease (Blum et al., 1997; Swanson et al., 2000; Zanker et al., 2000). In cattle, Lf is mainly produced in the mammary gland, increases during the dry period of late pregnancy, and is present in high amounts in the first C. Thereafter, its concentrations rapidly decrease during the first days of lactation (Neville and Zhang, 2000). In neonatal calves, Lf that is ingested with $\mathrm{C}$ is absorbed in the small intestine and appears in blood and in the brain (Lakritz et al., 2000; Talkuder et al., 2003). The existence of Lf receptors on the brush border membrane of the small intestine and on lymphocytes has been documented (Neville and Zhang, 2000; Talkuder et al., 2003). Lactoferrin modifies growth, and some evidence has been presented that Lf can influence the development of intestinal epithelia (Nichols et al., 1987; Hagiwara et al., 1995; Van Leeuwen et al., 2000). Lactoferrin is also known to be important for the function of immune-competent cells (Debbabi et al., 1998), as demonstrated in neonatal calves (Lakritz et al., 2000). Recently, important interactions among IGF binding protein-3, retinoic acid, and Lf have been documented in the bovine mammary gland (Baumrucker and Erondu, 2000). Because IGF binding protein-3 is the main IGF binding protein, modifications of the IGF system by retinoids and Lf in the GIT can also be expected. In this study, we have investigated effects of dietary bovine Lf and vitamin A alone or in combination on epithelia of the small inestine and colon and on gut-associated lymphoid tissues, especially of Peyer's patches (PP). We have also tested the hypothesis that there are interactions among vitamin A, Lf, and GIT development.

\section{MATERIALS AND METHODS}

\section{Experimental Procedures and Health Status}

Experimental procedures have been described in detail in a companion paper (Muri et al., 2005). In short, 35 male calves, born after $285 \pm 1 \mathrm{~d}$ of pregnancy, were studied. Five differently fed experimental groups were created, each consisting of 7 calves. Group F was fed a milk-based formula (F) that was not supplemented with vitamin A and Lf; whereas other groups were fed the same $\mathrm{F}$ in the same amounts as in group $\mathrm{F}$, but
Lf or vitamin A or vitamin A plus Lf were added. In the group fed $\mathrm{F}$ and supplemented with Lf but not with vitamin $\mathrm{A}\left(\mathbf{F}_{\mathbf{L}}\right), 3850,1990,660$, and $660 \mathrm{mg} / \mathrm{kg}$ of DM of $\mathrm{Lf}$ were added to the $\mathrm{F}$ that was fed on $\mathrm{d} 1,2,3$, and 4 , respectively. Another group was fed F supplemented with vitamin A but not with $\operatorname{Lf}\left(\mathbf{F}_{\mathbf{A}}\right) ; 351,402,490$, and $490 \mu \mathrm{mol} / \mathrm{kg}$ of $\mathrm{DM}$ of vitamin A were added to the formula that was fed on d 1,2,3, and 4, respectively. The other group was fed F supplemented with vitamin A and with $\mathrm{Lf}\left(\mathbf{F}_{\mathrm{AL}}\right) ; 351,402,490$, and 490 $\mu \mathrm{mol} / \mathrm{kg}$ of DM of vitamin A and 3850, 1990, 660, and $660 \mathrm{mg} / \mathrm{kg}$ of DM of Lf were added to the formula that was fed on $d 1,2,3$, and 4 , respectively. The Lf (DMV International, Veghel, The Netherlands) was of high purity (97\%) and was dissolved in double distilled water $(1 \mathrm{~g} / 20 \mathrm{~mL})$ for better handling and mixed in the formula immediately before feeding. Vitamin A was added during the production of the different formulas. A positive control group was fed colostrum $(\mathbf{C})$ that contained vitamin A and Lf. All calves were fed for 4 $\mathrm{d}$, but not on d 5 (day of euthanasia). Calves of the control (colostrum) group (C group) were fed pooled C obtained from milkings 1,3 , and 5 (d 1,2, and 3 of lactation, respectively) on the first 3 days of life and $\mathrm{C}$ of milking 5 was also fed on d 4 . Three milk-based F were fed on $d 1,2$, and 3 that contained amounts of nutrients similar to those of $\mathrm{C}$ milkings 1,3 , and 5, respectively. The formula of $\mathrm{d} 3$ was also fed on $\mathrm{d} 4$. Total fed amounts of $\mathrm{F}$ and $\mathrm{C}$ were $6 \%$ of BW on $\mathrm{d} 1$, $8 \%$ of BW on d 2, and $10 \%$ of BW on $\mathrm{d} 3$ and 4 . Calves were fed by bottle twice daily. To ensure that all calves received equal amounts of $\mathrm{F}$ or $\mathrm{C}$, calves with reduced appetite were also tube-fed to attain the desired amount of intake. Details of compositions (including contents of vitamin $\mathrm{A}$ and $\mathrm{Lf}$ ) of $\mathrm{C}$ and of $\mathrm{F}$ with and without supplemented vitamin A and Lf as well as on feeding have been described in the companion paper (Muri et al., 2005).

To protect against infections, $2 \mathrm{~g}$ of a bovine colostral Ig preparation (Gammaserin; Gräub AG, Berne, Switzerland) was injected subcutaneously before the first meal, and chicken egg-derived Ig that contained high antibody titers against rotavirus and pathogenic $E$. coli type K 99 (Globigen 88; Lohmann Animal Health, Cuxhaven, Germany) was fed (5, 4, 3, and $2 \mathrm{~g}$ on $\mathrm{d} 1$, 2,3 , and 4 , respectively). On $\mathrm{d} 2,3$, and 4 , calves were subcutaneously injected with antibiotics $(25 \mathrm{mg}$ Enrofloxacin/10 kg BW; Baytril 5\%; Bayer AG, Leverkusen, Germany). Navels were disinfected with Betadine (Mundipharma, Basel, Switzerland) after birth to protect from infection.

Blood samples were taken from jugular veins with evacuated tubes on d 1, 2, and 4 before and at 2 and $4 \mathrm{~h}$ after the first feeding and on $\mathrm{d} 3$ before feeding 
and on $\mathrm{d} 5$ before euthanasia to measure vitamin A and Lf concentrations. On d 4, blood was taken after the first feeding every $60 \mathrm{~min}$ for $8 \mathrm{~h}$ to measure plasma xylose concentrations. Tubes containing dipotassiumEDTA (1.8 g/L of blood) were kept on crushed ice until centrifuged at $1000 \times g$ for $20 \mathrm{~min}$. Supernatants were aliquoted and stored at $-20^{\circ} \mathrm{C}$.

\section{Laboratory Procedures}

Analyses in feeds and blood. Methods used to measure contents of feeds used in this study have been described (Muri et al., 2005). Plasma concentrations of Lf were measured by ELISA as described by Muri et al. (2005), of vitamin A with an HPLC method as described by van Merris et al. (2002), and of D-xylose as described by Hammon and Blum (1997).

Histomorphometry and histochemistry. After euthanasia on d 5 with $80 \mathrm{mg}$ of pentobarbital $/ \mathrm{kg}$ of BW (Eutha 77; Essex Animal Health, Friesoythe, Germany), the GIT was removed within 5 min and transferred into ice-cold PBS. Samples $(4 \times 4 \mathrm{~cm})$ of midduodenum, midjejunum, midileum, and midcolon were fixed on pieces of cork and transferred into PBS with paraformaldehyde ( $40 \mathrm{~g} / \mathrm{L}$ ). After $6 \mathrm{~h}$, three $1-\mathrm{mm}$ wide cross sections were cut from each intestinal sample, and after $24 \mathrm{~h}$, the samples were embedded in paraffin blocks. Fifteen longitudinal cuts of $5 \mu \mathrm{m}$ thickness were made from each intestinal sample.

To evaluate the number of proliferating cells, calves were injected intravenously with $500 \mathrm{mg}$ of 5-bromo2'-deoxyuridine (BrdU; \#280879; Roche Diagnostics $\mathrm{GmbH}$, Mannheim, Germany) 60 min before euthanasia. The laboratory procedures have been described in detail (Blättler et al., 2001; David et al., 2003; Norrman et al., 2003). To evaluate apoptotic rates, cells were visualized with terminal deoxynucleotidyl transferase-mediated X-dUTP nick end labeling (TUNEL) as described in detail (David et al., 2003; Norrman et al., 2003). To evaluate the number of T-lymphocytes $\left(\mathrm{CD}^{+}\right)$in $\mathrm{PP}$ and in the epithelium (intraepithelial lymphocytes) of the ileum, a polyclonal antibody (Clone D111M; Biomeda Corp., Hayward, CA) was used and to evaluate the number of B-lymphocytes $\left(\mathrm{CD}{ }^{+}\right)$a monoclonal mouse antihuman CD 79 $\alpha \mathrm{cy}-$ marker (Clone HM57; Dako) was used. Details of laboratory procedures have been described (Blättler et al., 2001; David et al., 2003; Norrman et al., 2003).

For histomorphometrical analyses, slide preparations were stained with hematoxylin and eosin. Digital microphotographs were obtained and evaluated with a graphics program (Corel Draw 9, Version 9.337; Corel Corporation, Ottawa, Ontario, Canada). The measurements of villus heights and crypt depths were done on at least 30 lengthwise cut, well-orientated crypt-villus preparations for each intestinal site. The thickness of submucosa and muscularis layers (each with 5 measurements) were measured for each intestinal site. Furthermore, circumferences, lengths, and widths of at least $10 \mathrm{PP}$ were evaluated. Intestinal epithelial cells $(n=2000)$ were counted along the crypts and along the total epithelium of each calf and intestinal site. The numbers of BrdU-labeled crypt cells per total crypt cells, and the number of BrdU-labeled cells per total epithelial cells were calculated.

The PP in the ileum (Figure 1) were evaluated for numbers of proliferating and apoptotic cells and for numbers of T- and B-lymphocytes. At least 5 different follicles, 4 interfollicular areas, and 3 domes were evaluated from each calf. A vertical axis was drawn through each follicle, interfollicular area, and dome. Three horizontal lines through each follicle (localized at 25,50 , and $75 \%$ on the vertical axis through the follicle), 2 horizontal lines through each interfollicular area (localized at 33 and $66 \%$ on the vertical axis of the interfollicular area), and 3 horizontal lines through each dome (localized at 25,50 , and $75 \%$ on the vertical axis through the domes) were drawn as described by David et al. (2003). Cells crossed by the lines were counted, and means of all lines were calculated and expressed as cell numbers per millimeter. Follicles of $\mathrm{PP}$ were separated into peripheral and central regions. Peripheral zones were defined to be within $15 \%$ of the edge of follicles, whereas central zones contained, correspondingly, about $70 \%$ of the area of follicles. Numbers of B-lymphocytes were counted along a line drawn through the follicle-associated epithelium. The intraepithelial lymphocytes were counted along a line drawn through the ileal epithelia (Figure 1) and expressed as number of positive cells per millimeter.

\section{Statistical Analyses}

Values were expressed as means \pm SEM. Data were normally distributed and evaluated using the GLM procedure of SAS (SAS Institute, 1994). Separate statistical models were used 1) to evaluate the effects of $\mathrm{Lf}$, vitamin $\mathrm{A}$, and $\mathrm{Lf} \times$ vitamin $\mathrm{A}$ interactions, 2) to compare effects of Lf and vitamin A with $\mathrm{C}$ feeding, and 3) to compare effects at different GIT sites. When the $F$-test was significant $(P<0.05)$, means were separated by Bonferroni $t$-test $(P<0.05)$. For correlations of morphometry, cell proliferation, apoptosis, and immune cells, the PROC CORR procedure of SAS was used. 


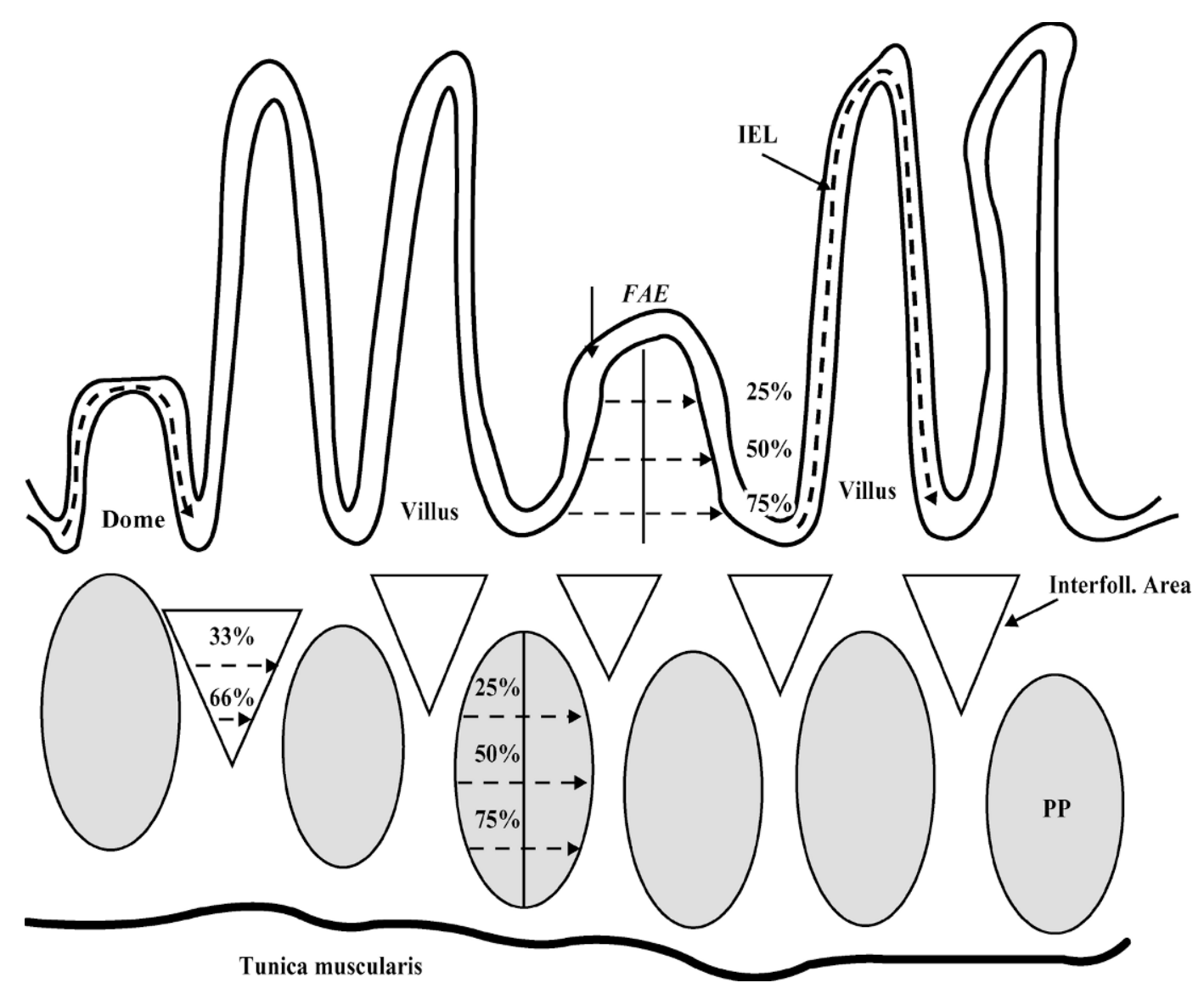

Figure 1. Schema of small intestinal structure with major emphasis on lymphoid tissues [Peyer's patches (PP) and intraepithelial lymphocytes]. Arrows $(\rightarrow)$ show the sites where the numbers of proliferating cells (based on incorporation of 5-bromo-2'-deoxyuridine), apoptotic cells (evaluated with TUNEL-assay; terminal deoxynucleotidyl transferase-mediated X -dUTP nick end labeling), T-lymphocytes (recognized by antihuman-CD 3-marker), and B- lymphocytes (recognized by antihuman-CD 79-marker) were evaluated. Interfoll. area = interfollicular area, IEL = intraepithelial lymphocytes, $F A E=$ follicular-associated epithelium.

\section{RESULTS}

\section{Plasma Vitamin A and Lactoferrin Status and Xylose Absorption}

Plasma Lf concentrations in the 5 groups after birth were similar (mean: $510 \pm 45 \mu \mathrm{g} / \mathrm{L}$ ), and in F-fed groups, preprandial plasma Lf concentrations did not change significantly (means of all $4 \mathrm{~F}$-fed groups preprandially on d $2,3,4$, and 5 were $761 \pm 63,569 \pm 42$, $498 \pm 40$, and $685 \pm 53 \mu \mathrm{g} / \mathrm{L}$, respectively). In group $\mathrm{C}$, plasma Lf concentrations increased after the first feeding on $\mathrm{d} 1$ from $550 \pm 43$ to $7447 \pm 1161 \mu \mathrm{g} / \mathrm{L}$ at 4 $\mathrm{h}$ postprandially, and then decreased to $3043 \pm 488$, $1034 \pm 113,765 \pm 78$, and $658 \pm 53 \mu / \mathrm{L}$ on $\mathrm{d} 2,3,4$, and 5, respectively. The Lf concentrations in group $\mathrm{C}$ were higher $(P<0.01)$ than in all $\mathrm{F}$-fed groups postprandially on $\mathrm{d} 1$ and 2 and preprandially on $\mathrm{d} 2$ and 3 .
Plasma vitamin A concentrations in group $\mathrm{F}$ decreased $(P<0.05)$ from $0.33 \pm 0.07 \mu \mathrm{mol} / \mathrm{L}$ at birth to $0.17 \pm 0.06 \mu \mathrm{mol} / \mathrm{L}$ on $\mathrm{d} 5$ and tended to decrease $(P<$ 0.1 ) in group $\mathrm{F}_{\mathrm{L}}$ from $0.24 \pm 0.06 \mu \mathrm{mol} / \mathrm{L}$ on $\mathrm{d} 1$ to 0.11 $\pm 0.01 \mu \mathrm{mol} / \mathrm{L}$ on $\mathrm{d} 5$. In contrast, plasma vitamin A concentrations increased $(P<0.001)$ in group $\mathrm{F}_{\mathrm{A}}$ from $0.16 \pm 0.03 \mu \mathrm{mol} / \mathrm{L}$ on $\mathrm{d} 1$ to $0.78 \pm 0.07 \mu \mathrm{mol} / \mathrm{L}$ on $\mathrm{d}$ 5 , in group $\mathrm{F}_{\mathrm{AL}}$ from $0.19 \pm 0.05 \mu \mathrm{mol} / \mathrm{L}$ on $\mathrm{d} 1$ to 0.70 $\pm 0.10 \mu \mathrm{mol} / \mathrm{L}$ on $\mathrm{d} 5$, and in group $\mathrm{C}$ from $0.19 \pm 0.03$ $\mu \mathrm{mol} / \mathrm{L}$ on $\mathrm{d} 1$ to $1.0 \pm 0.07 \mu \mathrm{mol} / \mathrm{L}$ on $\mathrm{d} 5$. Concentrations in group $\mathrm{C}$ were higher $(P<0.001)$ than in group $\mathrm{F}_{\mathrm{A}}$ on $\mathrm{d} 5$ and, in group $\mathrm{F}$, were lower $(P<0.01)$ than in groups $\mathrm{F}_{\mathrm{A}}$ and $\mathrm{C}$ from $\mathrm{d} 2$ to 5 .

Plasma concentration of xylose (Figure 2 ) increased $(P<0.001)$ in all 5 groups after feed intake and reached peak levels within $4 \mathrm{~h}$ after its oral administration. In group $\mathrm{C}$, xylose concentrations (areas under the curves) were higher $(P<0.05)$ than in $\mathrm{F}$-fed calves 


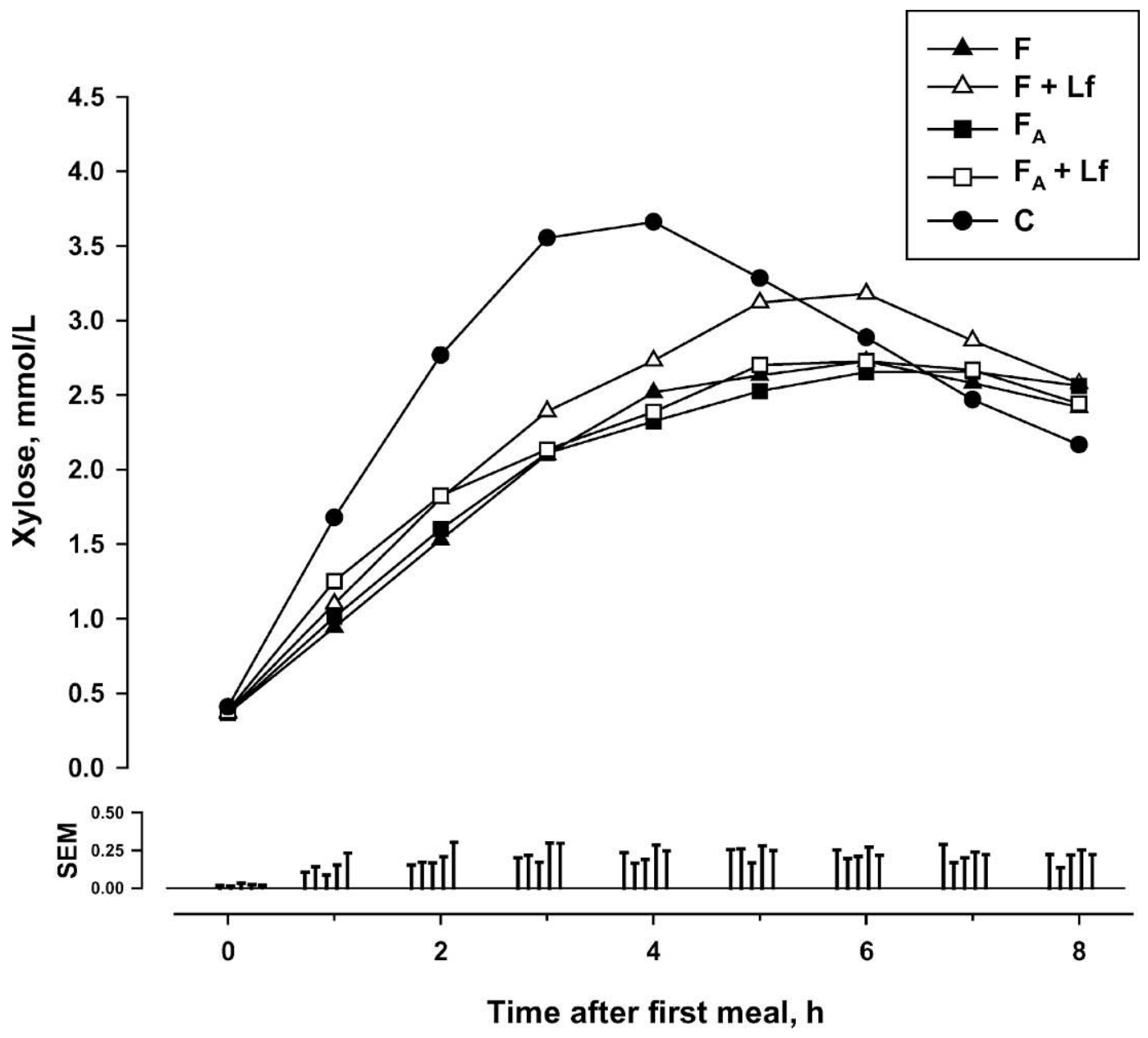

Figure 2. Intestinal xylose absorption (dose $=0.5 \mathrm{~g} / \mathrm{kg}$ ) on d 4 of life. Values are means ( $\mathrm{n}=7$ per group). The SEM of groups $\mathrm{F}(\mathbf{\Lambda})$; formula), $\mathrm{F}_{\mathrm{L}}\left[\Delta ; \mathrm{F}\right.$ plus lactoferrin (Lf)], $\mathrm{F}_{\mathrm{A}}(\mathbf{\square} ; \mathrm{F}$ plus vitamin $\mathrm{A}), \mathrm{F}_{\mathrm{AL}}(\square ; \mathrm{F}$ plus Lf plus vitamin $\mathrm{A})$, and $\mathrm{C}$ ( the bottom from the left to the right.

$[16.4 \pm 1.4,18.7 \pm 1.1,16.3 \pm 1.0,17.1 \pm 1.7$, and 21.6 $\pm 1.3 \mathrm{mmol} /(\mathrm{L} \times 8 \mathrm{~h})$ in groups $\mathrm{F}, \mathrm{F}_{\mathrm{L}}, \mathrm{F}_{\mathrm{A}}, \mathrm{F}_{\mathrm{AL}}$, and $\mathrm{C}$, respectively)]. In the duodenum, there was a significant correlation between the area under the curve of xylose concentrations and the villus height to crypt depth ratio $(\mathrm{r}=0.36 ; P<0.05)$.

\section{Histomorphometrical Analyses in Duodenum, Jejunum, lleum, and Colon}

Comparisons among different small intestine sites. Villus heights and villus height to crypt depth ratios were lower $(P<0.05)$ in the duodenum than in the jejunum and ileum, but these differences were not affected by treatments. Villus height to crypt depth ratios in the duodenum of groups $\mathrm{F}, \mathrm{F}_{\mathrm{L}}$, and $\mathrm{F}_{\mathrm{A}}$ were lower $(P<0.05)$, and of group $\mathrm{F}_{\mathrm{AL}}$ tended to be lower $(P<0.1)$, than in group C. Villus height to crypt depth ratios in the jejunum of group $\mathrm{F}$ were lower $(P<0.01)$, and of group $\mathrm{F}_{\mathrm{L}}$ tended to be lower $(P<0.1)$, than in group C. In addition, vitamin A treatment tended to increase $(P<0.1)$ villus height to crypt depth ratios in the jejunum. Villus heights in the ileum increased $(P<0.05)$ after vitamin A treatment. Crypt depths in the colon of group $\mathrm{F}_{\mathrm{AL}}$ were deeper $(P<0.05)$ than in the colon of group $\mathrm{C}$ (Table 1).

The lamina submucosa layer was thicker $(P<0.001)$ in ileum than in the duodenum and jejunum. In the jejunum, the submucosa layer tended to be reduced ( $P$ $<0.1)$, and in the colon was significantly thinner $(P<$ 0.05) in groups $\mathrm{F}_{\mathrm{A}}$ and $\mathrm{F}_{\mathrm{AL}}$ than in groups $\mathrm{F}$ and $\mathrm{F}_{\mathrm{L}}$.

The tunica muscularis layer was thicker $(P<0.05)$ in the duodenum than in the jejunum and ileum. In the duodenum, the tunica muscularis layer of group $\mathrm{F}_{\mathrm{L}}$ was thicker $(P<0.05)$ compared with group $\mathrm{C}$. 
Table 1. Histomorphometrical parameters of duodenum, jejunum, ileum, and colon in 5-d-old calves fed formula (F) without vitamin A and lactoferrin; or $\mathrm{F}$ supplemented with vitamin $\mathrm{A}\left(\mathrm{F}_{\mathrm{A}}\right)$, lactoferrin $\left(\mathrm{F}_{\mathrm{L}}\right)$, or vitamin $\mathrm{A}$ plus lactoferrin $\left(\mathrm{F}_{\mathrm{AL}}\right)$; or fed colostrum $(\mathrm{C})$. Values are means ( $\mathrm{n}=7$ per group).

\begin{tabular}{|c|c|c|c|c|c|c|c|c|c|}
\hline & \multicolumn{5}{|c|}{ Experimental group } & SEM & \multicolumn{3}{|c|}{ ANOVA $(P)^{1}$} \\
\hline \multicolumn{10}{|l|}{ Duodenum } \\
\hline Crypt depth, $\mu \mathrm{m}$ & 236 & 179 & 212 & 195 & 65 & 30 & NS & NS & NS \\
\hline Villus height to crypt depth ratio & $1.63^{*}$ & $1.74 *$ & $1.76^{*}$ & $1.91 \dagger$ & 2.71 & 0.23 & NS & NS & NS \\
\hline Submucosa, $\mu \mathrm{m}$ & 155 & 216 & 204 & 184 & 133 & 25 & NS & NS & NS \\
\hline Muscularis ext., $\mu \mathrm{m}$ & 346 & $445^{*}$ & 303 & 336 & 139 & 84 & NS & NS & NS \\
\hline Crypt depth, $\mu \mathrm{m}$ & 239 & 203 & 191 & 209 & 178 & 19 & NS & NS & NS \\
\hline Villus height to crypt depth ratio & $1.77^{*}$ & $2.46 \dagger$ & 2.75 & 2.48 & 3.67 & 0.25 & NS & $<0.1$ & NS \\
\hline Submucosa, $\mu \mathrm{m}$ & 374 & 267 & 184 & 176 & 287 & 72 & NS & $<0.1$ & NS \\
\hline Muscularis ext., $\mu \mathrm{m}$ & 152 & 174 & 172 & 165 & 144 & 24 & NS & NS & NS \\
\hline \multicolumn{10}{|l|}{ Ileum } \\
\hline Villus height, $\mu \mathrm{m}$ & 402 & 448 & 501 & 486 & 473 & 32 & NS & $<0.05$ & NS \\
\hline Circumference, $\mu \mathrm{m}$ & $1157^{\mathrm{b}}$ & 1462 & $1576^{\mathrm{a}}$ & 1493 & 1455 & 93 & NS & $<0.05$ & $<0.1$ \\
\hline Length, $\mu \mathrm{m}$ & $345^{\mathrm{b}}$ & 466 & $507^{\mathrm{a}}$ & 470 & 470 & 36 & NS & $<0.05$ & $<0.1$ \\
\hline \multicolumn{10}{|l|}{ Colon } \\
\hline Crypt depth, $\mu \mathrm{m}$ & 514 & 530 & 516 & $539 *$ & 405 & 33 & NS & NS & NS \\
\hline Submucosa, $\mu \mathrm{m}$ & 245 & 161 & 74 & 126 & 140 & 38 & NS & $<0.05$ & NS \\
\hline Muscularis ext., $\mu \mathrm{m}$ & 450 & 372 & 448 & 379 & 453 & 52 & NS & NS & NS \\
\hline
\end{tabular}

${ }^{\mathrm{a}, \mathrm{b}}$ Means with different superscripts among groups $\mathrm{F}$ and $\mathrm{F}_{\mathrm{A}}$ are different $(P<0.05)$.

${ }^{1} \mathrm{~L}=$ Lactoferrin effect, $\mathrm{A}=$ vitamin $\mathrm{A}$ effect, and $\mathrm{AL}=$ vitamin $\mathrm{A} \times$ lactoferrin interaction. There were no significant differences among groups $\mathrm{F}$ and $\mathrm{F}_{\mathrm{L}}$.

${ }^{2} P>0.1$.

*Differences among formula-fed groups and the colostrum-fed group $(P<0.05)$.

$\uparrow$ Differences among formula-fed groups and the colostrum-fed group $(P<0.1)$.

In the ileum, there tended to be interactions $(P<$ 0.1 ) between vitamin $A$ and $L f$ with respect to circumferences and lengths of $\mathrm{PP}$, and both were greater $(P<0.05)$ in group $\mathrm{F}_{\mathrm{A}}$ than in group $\mathrm{F}$. There were significant correlations $(\mathrm{r}=0.97 ; P<0.001)$ between lengths and circumferences of the $\mathrm{PP}$ in all of the groups and between follicle lengths $(\mathrm{r}=0.78 ; P<0.001)$ or circumferences $(\mathrm{r}=0.79 ; P<0.001)$ and submucosa thickness.

\section{Cell Proliferation in the Epithelium of Duodenum, Jejunum, lleum, and Colon}

In the small intestine, the numbers of BrdU-labeled crypt cells relative to total crypt cells and the numbers of total BrdU-labeled cells relative to total epithelial cells were closely correlated $(\mathrm{r}=0.89 ; P<0.001)$ and provided similar results (Table 2). The numbers of BrdU-labeled epithelial cells relative to total epithelial cells in duodenum were smaller $(P<0.001)$ than in the jejunum and ileum. The numbers of BrdU-labeled crypt cells relative to total crypt cells were different among intestinal sites (colon $>$ ileum $>$ jejunum $>$ duodenum). There were positive correlations between crypt depths and villus heights $(\mathrm{r}=0.32 ; P<0.01)$ and between crypt depths and the number of BrdU-labeled crypt cells relative to total crypt cells $(\mathrm{r}=0.28 ; P<0.01)$ if all data of the small intestine were considered. There were negative correlations between the number of BrdU-labeled cells relative to total epithelial cells and villus height in the jejunum $(\mathrm{r}=-0.51 ; P<0.01)$ and ileum ( $\mathrm{r}=-0.41 ; P<0.05)$ and between BrdU-labeled cells relative to total epithelial cells and villus height to crypt ratios $(\mathrm{r}=-0.32 ; P<0.001)$ if all data in the small intestine were considered.

Within F-fed calves, vitamin A supplementation affected $(P<0.05)$ the number of BrdU-labeled epithelial cells relative to total epithelial cells in the jejunum and ileum, and the number of BrdU-labeled epithelial cells relative to total epithelial cells in colon, but not in the duodenum, i.e., vitamin A supplementation resulted in reduced numbers of BrdU-labeled cells in groups $\mathrm{F}_{\mathrm{A}}$ and $\mathrm{F}_{\mathrm{AL}}$ relative to groups $\mathrm{F}$ and $\mathrm{F}_{\mathrm{L}}$. Within $\mathrm{F}$-fed groups, the Lf supplementation tended to affect $(P<$ 
Table 2. Cell proliferation in the duodenum, jejunum, ileum, and colon in 5-d-old calves fed formula (F) without vitamin A and lactoferrin; with vitamin $\mathrm{A}\left(\mathrm{F}_{\mathrm{A}}\right)$, lactoferrin $\left(\mathrm{F}_{\mathrm{L}}\right)$, or vitamin A plus lactoferrin $\left(\mathrm{F}_{\mathrm{AL}}\right)$; or fed colostrum $(\mathrm{C})$. Cell proliferation rates were based on counting crypt epithelial cells that were labeled with 5'-bromo-2'-deoxyuridine (BrdU). Values are means $(\mathrm{n}=7$ per group).

\begin{tabular}{|c|c|c|c|c|c|c|c|c|c|}
\hline \multirow[b]{2}{*}{ Item } & \multicolumn{5}{|c|}{ Experimental group } & \multirow[b]{2}{*}{ SEM } & \multicolumn{3}{|c|}{$\operatorname{ANOVA}(P)^{1}$} \\
\hline & $\mathrm{F}$ & $\mathrm{F}_{\mathrm{L}}$ & $\mathrm{F}_{\mathrm{A}}$ & $\mathrm{F}_{\mathrm{AL}}$ & $\mathrm{C}$ & & $\mathrm{L}$ & $\mathrm{A}$ & $\mathrm{AL}$ \\
\hline \multicolumn{10}{|l|}{ Duodenum } \\
\hline BrdU-labeled cells/total villus cells $\times 100$ & $11.8^{*}$ & $10.6 \dagger$ & 8.8 & 9.4 & 6.6 & 1.2 & NS & NS & NS \\
\hline \multicolumn{10}{|l|}{ Jejunum } \\
\hline BrdU-labeled crypt cells/total crypt cells $\times 100$ & $35.9 *$ & $34.5 \dagger$ & 27.0 & 27.8 & 25.3 & 2.6 & NS & $<0.05$ & NS \\
\hline BrdU-labeled cells/total villus cells $\times 100$ & $16.9 *$ & $13.9 \dagger$ & 9.6 & 11.0 & 8.2 & 1.4 & NS & $<0.01$ & NS \\
\hline BrdU-labeled cells/total villus cells $\times 100$ & $23.9^{*, \mathrm{a}}$ & $18.4^{*}$ & $12.8^{\mathrm{b}}$ & 14.7 & 9.9 & 1.4 & NS & $<0.001$ & $<0.05$ \\
\hline \multicolumn{10}{|l|}{ Colon } \\
\hline BrdU-labeled crypt cells/total crypt cells $\times 100$ & $27.9^{*, \mathrm{a}, \mathrm{c}}$ & $17.9^{\mathrm{d}}$ & $14.3^{\mathrm{b}}$ & 15.6 & 12.2 & 2.1 & $<0.1$ & $<0.01$ & $<0.05$ \\
\hline
\end{tabular}

${ }^{\mathrm{a}, \mathrm{b}}$ Means among formula-fed groups $\mathrm{F}$ and $\mathrm{F}_{\mathrm{A}}$ with different superscripts are different $(P<0.05)$.

${ }^{\mathrm{c}, \mathrm{d}}$ Means among formula-fed groups $\mathrm{F}$ and $\mathrm{F}_{\mathrm{L}}$ with different superscripts are different $(P<0.05)$.

${ }^{1} \mathrm{~L}=$ Lactoferrin effect, $\mathrm{A}=$ vitamin $\mathrm{A}$ effect, and $\mathrm{AL}=$ lactoferrin $\times$ vitamin $\mathrm{A}$ interaction.

${ }^{2} P>0.1$.

$\dagger$ Differences among formula-fed groups and the colostrum-fed group $(P<0.1)$.

*Differences among formula-fed groups and the colostrum-fed group $(P<0.05)$.

0.1) the number of BrdU-labeled epithelial cells relative to total epithelial cells in the colon, i.e., proliferating cells were reduced in group $\mathrm{F}_{\mathrm{L}}$ relative to group $\mathrm{F}$. Within $\mathrm{F}$-fed calves, there were significant interactions $(P<0.05)$ between vitamin A and Lf supplementation in the ileum and colon. In the ileum and colon, the number of BrdU-labeled epithelial cells was higher $(P$ $<0.001$ ) in group $\mathrm{F}$ than in group $\mathrm{F}_{\mathrm{A}}$, and in the colon, the number of BrdU-labeled epithelial cells in group $\mathrm{F}$ was higher $(P<0.05)$ than in group $\mathrm{F}_{\mathrm{L}}$ and higher $(P$ $<0.05$ ) than in group $\mathrm{C}$.

\section{Cell Proliferation, Apoptosis, and Numbers of T- and B-Lymphocytes in PP of the lleum}

The number of BrdU-labeled cells in follicles, interfollicular areas, and domes was similar among the 5 groups, was 2.2 times higher in peripheral than in central regions of follicles $(P<0.001)$, and was different at the various sites of the $\mathrm{PP}$ [follicles $>$ interfollicular areas $>$ domes; $P<0.001$ (data not shown)] if values of all groups were considered. The number of proliferating cells was not affected by Lf and vitamin A, and there were no $\mathrm{Lf} \times$ vitamin A interactions (Table 3 ).

The number of TdT3'-end labeled cells in follicles, interfollicular areas, and domes of PP was similar in the 5 groups, was higher $(P<0.001)$ in follicles than in domes and interfollicular areas, and was similar in peripheral and in central areas of follicles if values of all groups were considered (data not shown). The number of TdT3'-end labeled cells was not affected by Lf and vitamin $\mathrm{A}$, and there were no $\mathrm{Lf} \times$ vitamin $\mathrm{A}$ interactions.

The numbers of T-lymphocytes (cluster of differentiation: 3-positive) in follicles and interfollicular areas were similar in all 5 groups. In F-fed groups, the numbers of T-lymphocytes in domes were reduced by vitamin A treatment, and the reduction was more pronounced in non-LF fed calves. The number of T-lymphocytes in domes was higher $(P<0.05)$ in group $\mathrm{F}$ than in group $\mathrm{C}$. The distribution of T-lymphocytes within $\mathrm{PP}$ was different [interfollicular areas $>$ intraepithelial lymphocytes $>$ domes $\geq$ follicles; $P<0.001$ (data not shown)]. Numbers of T-lymphocytes and BrdU-labeled cells tended to correlate in interfollicular areas $(\mathrm{r}=$ $0.32 ; P<0.1)$ and significantly correlated in domes $(\mathrm{r}=$ $0.35 ; P<0.05)$.

The numbers of B-lymphocytes (cluster of differentiation: 79-positive) in the 5 groups were similar. The number of B-lymphocytes was different at the various PP sites (follicles $>$ interfollicular area $>$ domes $\geq$ follicleassociated epithelium; $P<0.001$ ). In follicles of PP, if all groups are considered, the number of B-lymphocytes was 1.3 times higher in peripheral regions than in central regions (data not shown). The numbers of B-lymphocytes and BrdU-labeled cells and in follicles were significantly correlated $(\mathrm{r}=0.44 ; P<0.01)$.

\section{DISCUSSION}

\section{Vitamin A and Lf Status}

Plasma vitamin A concentrations of $\mathrm{C}$-fed or of vitamin A-supplemented calves (groups $\mathrm{C}, \mathrm{F}_{\mathrm{A}}$, and $\mathrm{F}_{\mathrm{AL}}$ ) 
Table 3. Cell proliferation, apoptosis, and T- and B-lymphocytes in the ileum of calves fed formula (F) without vitamin $A$ and lactoferrin; or supplemented with vitamin $A\left(F_{A}\right)$, lactoferrin $\left(F_{L}\right)$, or vitamin $A$ plus lactoferrin $\left(\mathrm{F}_{\mathrm{AL}}\right)$; or with colostrums $(\mathrm{C})$.

\begin{tabular}{|c|c|c|c|c|c|c|c|c|c|}
\hline & \multicolumn{5}{|c|}{ Experimental group } & \multirow[b]{2}{*}{ SEM } & \multicolumn{3}{|c|}{$\operatorname{ANOVA}(P)^{1}$} \\
\hline & $\mathrm{F}$ & $\mathrm{F}_{\mathrm{L}}$ & $\mathrm{F}_{\mathrm{A}}$ & $\mathrm{F}_{\mathrm{AL}}$ & $\mathrm{C}$ & & $\mathrm{L}$ & $\mathrm{A}$ & $\mathrm{AL}_{18}$ \\
\hline \multicolumn{10}{|l|}{ BrdU-labeled cells $/ \mathrm{mm}^{2}$} \\
\hline Follicles of PP & 52.7 & 44.1 & 44.3 & 45.9 & 45.3 & 2.9 & $\mathrm{NS}^{3}$ & NS & NS \\
\hline Interfollicular areas of $\mathrm{PP}$ & 16.1 & 16.8 & 16.4 & 16.8 & 14.1 & 3.1 & NS & NS & NS \\
\hline Domes of PP & 9.8 & 8.8 & 8.3 & 7.4 & & 1.7 & NS & NS & NS \\
\hline \multicolumn{10}{|l|}{ TdT3'-end labeled cells $/ \mathrm{mm}^{4}$} \\
\hline Follicles of PP & 7.4 & 5.8 & 8.8 & 6.7 & 6.6 & 1.0 & NS & NS & NS \\
\hline Interfollicular areas of PP & 2.0 & 1.1 & 1.6 & 2.9 & 0.8 & 0.8 & NS & NS & NS \\
\hline Domes of PP & 3.0 & 4.3 & 2.4 & 1.9 & 1.7 & 0.6 & NS & NS & NS \\
\hline \multicolumn{10}{|l|}{ T-lymphocytes/mm } \\
\hline Follicles of PP & 0.8 & 0.5 & 0.4 & 0.4 & 0.6 & 0.2 & NS & NS & NS \\
\hline Interfollicular areas of $\mathrm{PP}$ & 84.4 & 105.5 & 90.0 & 90.5 & 77.7 & 7.5 & NS & NS & NS \\
\hline Domes of PP & $25.0 *$ & 12.5 & 4.9 & 8.4 & 8.3 & 3.8 & NS & $<0.01$ & $<0.1$ \\
\hline Intra-epithelial lymphocytes & 66.9 & 75.3 & 67.6 & 72.4 & 85.0 & 10.8 & NS & NS & NS \\
\hline \multicolumn{10}{|l|}{ B-lymphocytes/mm } \\
\hline Follicles of PP & 159.9 & 150.8 & 139.3 & 138.8 & 153.5 & 8.4 & NS & NS & NS \\
\hline Interfollicular areas of PP & 18.9 & 10.3 & 12.4 & 11.9 & 12.1 & 3.5 & NS & NS & NS \\
\hline Domes of PP & 27.0 & 41.8 & 33.3 & 36.0 & 41.8 & 7.7 & NS & NS & NS \\
\hline Follicle-associated epithelium & 15.9 & 18.8 & 10.4 & 11.5 & 13.9 & 3.1 & NS & NS & NS \\
\hline
\end{tabular}

${ }^{1} \mathrm{~L}=$ Lactoferrin effects, $\mathrm{A}=$ vitamin $\mathrm{A}$ effects, and $\mathrm{AL}=$ vitamin $\mathrm{A} \times$ lactoferrin interaction.

${ }^{2}$ Proliferation rates in Peyer's Patches (PP) was based on counting 5-bromo-2'deoxyuridine (BrdU)-labeled cells.

${ }^{3} P>0.1$.

${ }^{4}$ Apoptotic rates were evaluated based on counting terminal deoxynucleotidyl transferase-mediated XdUTP nick end labeled cells. Evaluation of the number of B- and (or) T-lymphocytes was based on CD 79 and CD 3-cell surface marker, respectively. Values are means ( $n=7$ per group) except means of $n=5$ per group.

*Difference among formula-fed groups and the colostrum-fed group $(P<0.05)$.

increased on $\mathrm{d} 2$ to 5 , as expected (Hidiroglou and Markham, 1996; Blum et al., 1997; Franklin et al., 1998; Zanker et al., 2000). The plasma vitamin A level of calves of all groups immediately after birth was low and remained low in F-fed calves that were not supplemented with vitamin A, as previously shown (Blum et al., 1997; Franklin et al., 1998; Nonnecke et al., 2000). No clinical signs of vitamin A deficiency were observed in calves that were fed the $\mathrm{F}$ without vitamin $\mathrm{A}$, despite a decrease of vitamin A plasma levels through $5 \mathrm{~d}$ of age, likely because the vitamin A depletion period was not long enough to cause clinical or pathological signs of deficiency, as discussed (Muri et al., 2005). In Ffed groups that were supplemented with several times higher amounts of vitamin $\mathrm{A}$ than present in $\mathrm{C}$, lower plasma vitamin A concentrations were measured than in C-fed calves, likely because of the lower absorption rates and (or) enhanced metabolic clearance rates, as discussed (Muri et al., 2005). A higher absorptive capacity of the small intestine is supported by the enhanced appearance of xylose in blood plasma of C-fed calves than of F-fed calves, although it is well known that the absorptive mechanisms of vitamin $\mathrm{A}$ and xylose are different. The possibility that absorbed $\beta$-carotene of
C might have been converted to vitamin $\mathrm{A}$, and thus contributed to the high plasma vitamin A levels in the C-fed group, has been discussed (Muri et al., 2005).

Plasma Lf concentrations increased in C-fed calves, as expected (Lakritz et al., 2000; Talkuder et al., 2003). Surprisingly, plasma Lf concentrations in all F-fed groups remained similarly low up to $4 \mathrm{~d}$, independent from whether Lf was added to the $\mathrm{F}$ or not. Obviously, Lf added to $\mathrm{F}$ was not absorbed. The causes are not clear (Muri et al., 2005).

\section{Epithelial Cell Proliferation in the Small Intestine and Colon and Crypt and Villus Sizes}

Colostrum effects. Colostrum feeding enhances intestinal growth, as shown in several species, including calves (Bühler et al., 1998; Blättler et al., 2001; Roffler et al., 2003; Sauter et al., 2004). Although in this study, no crypt depth and villus height differences in the small intestine were found among $\mathrm{C}$-fed and $\mathrm{F}$-fed calves, the villus height to crypt depth ratios in the duodenum and jejunum in C-fed calves were higher (significantly or numerically) than in F-fed groups. Crypt cell proliferation rates were reduced in $\mathrm{C}$-fed calves as compared 
with F-fed calves (groups $\mathrm{F}$ and $\mathrm{F}_{\mathrm{L}}$ ). Vitamin $\mathrm{A}$ in $\mathrm{C}$ might have reduced proliferation rates, similar to those found in F-fed calves that were supplemented with vitamin A. Because the crypt cell proliferation rates were negatively associated with villus heights, other mechanisms likely contributed to enhanced villus height to crypt depth ratio in C-fed calves, such as reduced apoptotic rates of crypt cells, enhanced migration rates of cells from crypts to tips of villi, or increased survival or reduced turnover rates of differentiated villus epithelial cells. The number of apoptotic crypt cells was so small that an evaluation was not possible, and apoptotic cells at villus tips were not observed (data not shown).

Plasma xylose concentrations increased more in Cfed calves than in F-fed calves. A greater absorptive capacity in other studies was explained by greater small intestinal villus sizes (Hammon and Blum, 1997; Sauter et al., 2004). In accordance, in the present study, a positive, although low, correlation between the area under the curve of plasma xylose concentrations and the villus height to crypt depth ratio was found, albeit only in the duodenum, where xylose is primarily absorbed.

Effects of vitamin A supplemention. In F-fed calves that were supplemented with vitamin A, villus heights in the ileum and villus height to crypt depth ratios in the jejunum were enhanced. The relatively enhanced villus heights in our study in response to vitamin A supplementation were in agreement with studies in Xenopus laevis (Weissmann, 1961) and in pigs (Yuen and Stratford, 2004). However, vitamin A supplementation reduced BrdU incorporation into crypt cells in the jejunum, ileum, and colon in the actual study. This is in agreement with reduced mammary gland or colon cancer epithelial cell proliferation by high amounts of vitamin A (Woodward et al., 1996; Maziere et al., 1997). Different vitamin A effects at different GIT sites were surprising, and this may be explained by different distribution of retinoic acid receptors at different GIT sites. Different expression patterns of other receptors at different GIT sites have been noted in neonatal calves (Georgiev et al., 2003; Ontsouka et al., 2004).

In our study, there were no effects of vitamin A deficiency on intestinal epithelia. However, vitamin A deficiency is known to have effects on GIT epithelial cells, although the data are conflicting. Thus, crypt cell proliferation rate in the small intestine of vitamin A-deficient rats and chickens was enhanced (Reifen et al., 1998; Uni et al., 2000), although cell proliferation rates in other studies were not affected (Zile et al., 1981; Warden et al.,1996). During vitamin A deficiency, reduced cell maturation was reported (Uni et al., 2000). Further- more, the cell cycle of jejunal epithelial cells was prolonged mainly because of a prolonged DNA synthesis phase (Zile et al., 1981). Because BrdU becomes incorporated into DNA only in the S-phase (Yanai et al., 1996), more epithelial cells are likely labeled in a given time ( $1 \mathrm{~h}$ in our study), although the whole process of mitosis may not necessarily be enhanced. Vitamin A deficiency can also enhance apoptotic rates of crypt cells (SwartzBasile et al., 2003). In addition, a slower epithelial cell migration rate from crypts up to villus tips was found in vitamin A-deficient rats (Zile et al., 1981; SwartzBasile et al., 2003). Furthermore, losses of cells from villus tips were enhanced, and enterocyte sizes were reduced (Uni et al., 1998). Thus, several factors (prolonged cell cycles, reduced enterocyte sizes, reduced migration rates from crypt to villus tips, enhanced apoptotic rates of crypt cells, enhanced losses of epithelial cells from villus tips) are likely involved in reduced epithelial growth and regeneration during vitamin A deficiency. The short duration of our study (4 d) was most likely not sufficient to demonstrate such effects.

Effects of $\boldsymbol{L}$. . Lactoferrin supplementation among Ffed calves did not affect histomorphometrical measures of the intestinal epithelium. However, crypt cell proliferation was negatively affected by Lf supplementation, albeit only in the colon (smaller number of BrdU-labeled crypt cells in group $F_{L}$ than in group $F$ ). This was in contrast to Nichols et al. (1987) and Hagiwara et al. (1995). That effects of Lf on BrdU incorporation were only visible in the colon, but not in the small intestine, might have been due to differences in characteristics of luminal contents (as for example $\mathrm{pH}$, type, and numbers of microorganisms) that may affect interaction of Lf with its receptors in the GIT. Our data on reduced BrdU incorporation into crypt cells in the colon of Lfsupplemented calves are in agreement with Damiens et al. (1999) and Tsuda et al. (2002), who reported that $\mathrm{Lf}$ administration reduces the $\left({ }^{3} \mathrm{H}\right)$-thymidine incorporation into colon cancer epithelial cells and human mammary epithelial cells in vitro and in vivo. The antiproliferative activity of $\mathrm{Lf}$ was induced through growth arrest between the $G_{1}$ and $S$ phase of the cell cycle (Damiens et al., 1999). The inhibition of crypt cell proliferation could compensate for a longer-lasting cell cycle, as described by Zile et al. (1981) and reduce the BrdUlabeling as shown in our study in the colon.

Vitamin $A$ and $L f$ interactions. Interestingly, there were significant interactions between vitamin A and Lf with respect to crypt cell proliferation not only in the colon, but also in the ileum (i.e., the decreased BrdU incorporation into crypt cells of the colon in Lfsupplemented calves was associated with enhanced crypt cell proliferation in the colon of calves not supple- 
mented with vitamin A and Lf). Important interactions among Lf, vitamin A (and specifically with retinoic acid), and other systems (IGF binding protein-3) have been reported for the bovine mammary gland (Baumrucker and Erondu, 2000).

\section{Submucosa and Muscle Layer Thickness}

The submucosa layer was thicker in the ileum than in the duodenum and jejunum, as found previously (Sauter et al., 2004). Interestingly, the submucosa thickness was negatively influenced by the vitamin A status in the jejunum and the colon (significantly only in the colon). No such data have to our knowledge been reported before. That only the jejunum and colon were affected was, however, surprising and supports other histological effects of vitamin A that varied among different GIT sites.

The thickness of the tunica muscularis layer in the small intestine was similar to that of another study (Roffler et al., 2003), and the layer was significantly thicker in duodenum than in the jejunum and ileum. Only the duodenum of group $\mathrm{F}_{\mathrm{L}}$ had a thicker tunica muscularis layer than group $\mathrm{C}$, indicating that orally administered Lf might have an effect not only on protein synthesis (Burrin et al., 1996), but also only on GIT muscle synthesis.

\section{Effects on Size of PP, Cell Proliferation, Apoptosis, T-Lymphocytes, and B-Lymphocytes in the lleum}

The distribution of T-cells and B-cells in PP, interfollicular areas, domes, and in the epithelium was as described by David et al. (2003) and Norrman et al. (2003). The number of positively labeled T- and B-cells deviated in part from these values, likely because of the use of different antibodies and slightly different staining methods.

That vitamin A (Elitsur et al., 1997; Bjersing et al., 2002) and Lf (Debbabi et al., 1998; Sfeir et al., 2004) exert effects on lymphoid tissues in the GIT has been documented. In the present study, we found significant effects of vitamin A, and there was a tendency for interactions between vitamin A and Lf effects on PP sizes of the ileum among groups fed the $\mathrm{F}$ with and without vitamin $\mathrm{A}$. This demonstrates that vitamin A alone enhanced PP sizes and that vitamin A interaction with Lf exerted biological effects on lymphoid tissues of the small intestine. Whether effects of vitamin A, alone or in combination with Lf, on the PP size were due to effects other than on lymphocyte numbers is not clear.

Effects of vitamin A and interactions between vitamin A and Lf were only seen with respect to the number of T-lymphocytes (reduction) in the domes of PP. Possibly the duration ( $4 \mathrm{~d}$ ) of vitamin A and Lf administration was too short to have greater effects and also effects on lymphocytes of other compartments. That there were no effects on proliferation and apoptosis rates in the different lymphocyte compartments of the ileum suggests that the reduced number of T-lymphocytes in vitamin A-supplemented calves was possibly due to enhanced escape of these cells from domes. Redistribution of lymphocytes in domes has been shown to occur after dexamethasone treatment in neonatal calves (Norrman et al., 2003).

\section{CONCLUSIONS}

The present study demonstrates effects of $\mathrm{C}$ intake and of F-supplemented vitamin $\mathrm{A}$ and Lf, alone, and (or) in combination, on the development of the gut epithelium of neonatal calves up to $5 \mathrm{~d}$ of age. Effects on cell proliferation in the intestinal epithelium mainly in the jejunum and ileum were documented, but morphological effects were only observed in villi of ileum and in crypts of the large intestine. Increased follicle sizes of PP were seen in vitamin A-supplemented calves and vitamin A selectively affected the number of T lymphocytes in domes. Although effects were relatively small, in part due to the short duration of the study, they may be of importance for gastrointestinal health during the first days of life.

\section{ACKNOWLEDGMENTS}

This investigation was in part supported by Swiss National Science Foundation (grant \#32-67205.01). We thank M. Stoffel (Institute of Veterinary Anatomy, Vetsuisse Faculty, University of Berne) and M. Bozzo (Institute of Veterinary Pathology, Vetsuisse Faculty, University of Berne) for their help in histological analyses, Y. Aeby and the staff (Federal Research Station Agroscope, Liebefeld-Posieux, Switzerland) for putting calves at our disposal, and E. Husman (UFA AG, Sursee, Switzerland) for helping us to develop the milkbased formula. Special thanks go to G. Puvogel (Division of Nutrition and Physiology) for his constructive support.

\section{REFERENCES}

Baumrucker, C. R., and N. E. Erondu. 2000. Insulin-like growth factor (IGF) system in the bovine mammary gland and milk. J. Mammary Gland Biol. Neoplasia 5:53-64.

Bjersing, J. L., E. Telemo, U. Dahlgren, and L. A. Hanson. 2002. Loss of ileal IgA-positive plasma cells and of CD4-positive lymphocytes 
in ileal Peyer's patches of vitamin A deficient rats. Clin. Exp. Immunol. 130:404-408.

Blättler, U., H. M. Hammon, C. Morel, C. Philipona, A. Raupich, V. Romé, I. Le Huerou-Luron, P. Guilloteau, and J. W. Blum. 2001. Feeding colostrum, its composition and feeding duration variably modify proliferation and morphology of the intestine and digestive enzyme activities of neonatal calves. J. Nutr. 131:1256-1263.

Blomhoff, H. K., E. B. Smeland, B. Erikstein, A. M. Rasmussen, B. Skrede, C. Skjonsberg, and R. Blomhoff. 1992. Vitamin A is a key regulator for cell growth, cytokine production, and differentiation in normal B cells. J. Biol. Chem. 267:23988-23992.

Blum, J. W., and C. R. Baumrucker. 2002. Colostral and milk insulinlike growth factors and related substances: Mammary gland and neonatal (intestinal and systemic) targets. Domest. Anim. Endocrinol. 23:101-110.

Blum, J. W., U. Hadorn, H. P. Sallmann, and W. Schuep. 1997. Delaying colostrum intake by one day impairs plasma lipid, essential fatty acid, carotene, retinol and $\alpha$-tocopherol status in neonatal calves. J. Nutr. 127:2024-2029.

Bühler, C., H. Hammon, G. L. Rossi, and J. W. Blum. 1998. Small intestinal morphology in eight-day-old calves fed colostrum for different durations or only milk replacer and treated with longR3-insulin-like growth factor I and growth hormone. J. Anim. Sci. 76:758-765.

Burrin, D. G., H. Wang, J. Heath, and M. A. Dudley. 1996. Orally administered lactoferrin increases hepatic protein synthesis in formula-fed newborn pigs. Pediatr. Res. 40:72-76.

Damiens, E., I. E. Yazidi, J. Mazurier, I. Duthille, and G. Spik. 1999. Lactoferrin inhibits G1 cyclin-dependent kinases during growth arrest of human breast carcinoma cells. J. Cell. Biochem. 74:486-498.

David, C. W., J. Norrman, H. M. Hammon, W. C. Davis, and J. W. Blum. 2003. Cell proliferation, apoptosis, and B- and T-lymphocytes in Peyer's patches of the ileum, in thymus and in lymphnodes of preterm calves and in full-term calves at birth and on day 5 of life. J. Dairy Sci. 86:3321-3329.

Debbabi, H., M. Dubarry, M. Rautureau, and D. Tome. 1998. Bovine lactoferrin induces both mucosal and systemic immune responses in mice. J. Dairy Res. 65:283-293.

Elitsur, Y., C. Neace, X. Liu, J. Dosescu, and J. A. Moshier. 1997. Vitamin A and retinoic acids immunomodulation on human gut lymphocytes. Immunopharmocology 35:247-253.

Franklin, S. T., C. E. Sorensen, and D. C. Hammell. 1998. Influence of vitamin A supplementation in milk on growth, health, concentrations of vitamins in plasma, and immune parameters of calves. J. Dairy Sci. 81:2623-2632.

Georgiev, I. P., T. M. Georgieva, M. Pfaffl, H. M. Hammon, and J. W. Blum. 2003. Insulin-like growth factor and insulin receptors in intestinal mucosa of neonatal calves. J. Endocrinol. 176:121-132.

Hagiwara, T., I. Shinoda, Y. Fukuwatrai, and S. Shimamura. 1995. Effects of lactoferrin and its peptides on proliferation of rat intestinal epithelial cell line, IEC-18, in the presence of epidermal growth factor. Biosci. Biotechnol. Biochem. 59:1875-1881.

Hammon, H., and J. W. Blum. 1997. Prolonged colostrum feeding enhances xylose absorption in neonatal calves. J. Anim. Sci. 75:2915-2919.

Hidiroglou, M., and F. Markham. 1996. Effect of oral supplements of vitamin A on plasma retinol levels in calves and their immunological responsiveness. Reprod. Nutr. Dev. 36:467-472.

Lakritz, J., J. W. Tyler, D. E. Hostetler, A. E. Marsh, D. M. Weaver, J. M. Holle, B. J. Steevens, and J. L. Denbigh. 2000. Effects of pasteurization of colostrum on subsequent serum lactoferrin concentration and neutrophil superoxide production in calves. Am. J. Vet. Res. 61:1021-1025.

Maziere, S., P. Cassand, J. F. Narbonne, and K. Meflah. 1997. Vitamin A and apoptosis in colonic tumor cells. Int. J. Vitam. Nutr. Res. 67:237-241.

Muri, C., T. Schottstedt, H. M. Hammon, E. Meyer, and J. W. Blum. 2005. Hematological, metabolic and endocrine effects of feeding vitamin A and lactoferrin in neonatal calves. J. Dairy Sci. 88:1062-1077.
Neville, M. C., and P. Zhang. 2000. Lactoferrin secretion into milk: Comparison between ruminant, murine, and human milk. J. Anim. Sci. 78(Suppl.):26-35.

Nichols, B. L., K. S. McKee, J. F. Henry, and M. Putman. 1987. Human lactoferrin stimulates thymidine incorporation into DNA of rat crypt cells. Pediatr. Res. 21:563-567.

Nonnecke, B. J., R. L. Horst, D. C. Hammell, and S. T. Franklin. 2000. Effects of supplemental vitamin A on retinoic acid concentration in the plasma of preruminant calves. Int. J. Vitam. Nutr. Res. 70:278-286.

Norrman, J., C. W. David, S. N. Sauter, H. M. Hammon, and J. W. Blum. 2003. Effects of dexamethasone on lymphoid tissue in the gut and thymus of neonatal calves fed with colostrum and milk replacer. J. Anim. Sci. 81:2322-2332.

Ontsouka, E. C., H. M. Hammon, and J. W. Blum. 2004. Expression of insulin-like growth factors (IGF)-1 and -2, IGF binding proteins-2 and -3 , and receptors for growth hormone, IGF type- 1 and -2 and insulin in the gastrointestinal tract. Growth Factors 22:63-69.

Reifen, R., G. Zaiger, and Z. Uni. 1998. Effects of vitamin A on small intestinal brush border enzymes in a rat. Int. J. Vit. Nutr. Res. 86:281-286

Roffler, B., A. Fäh, S. N. Sauter, H. M. Hammon, P. Gallmann, G. Brem, and J. W. Blum. 2003. Intestinal morphology, epithelial cell proliferation, and absorptive capacity in neonatal calves fed milk-born insulin-like growth factor-1 or a colostrum extract. J. Dairy Sci. 86:1797-1806.

SAS. 1994. Introductory Comparison of the GLM and Mixed Procedure. SAS Inst., Inc., Cary, NC.

Sauter, S. N., B. Roffler, C. Philipona, C. Morel, V. Rome, P. Guilloteau, J. W. Blum, and H. M. Hammon. 2004. Intestinal development in neonatal calves: Effects of glucocorticoids and dependence on colostrum feeding. Biol. Neonate 85:94-104.

Sfeir, R. M., M. Dubarry, P. N. Boyaka, M. Rautureau, and D. Tome. 2004. The mode of oral bovine lactoferrin administration influences mucosal and systemic immune responses in mice. J. Nutr. 134:403-409.

Swanson, K. S., N. R. Merchen, J. W. Erdman, J. K. Drackley, F. Orias, D. E. Morin, and M. F. Haddad. 2000. Influence of dietary vitamin A content on serum and liver vitamin A concentrations and health in preruminant Holstein calves fed milk replacer. J. Dairy Sci. 83:2027-2036.

Swartz-Basile, D. A., L. Wang, Y. Tang, H. A. Pitt, D. C. Rubin, and M. S. Levin. 2003. Vitamin A deficiency inhibits intestinal adaptation by modulating apoptosis, proliferation, and enterocyte migration. Am. J. Physiol. 285:G424-G432.

Talkuder, M. J. R., T. Takeuchi, and E. Harada. 2003. Receptormediated transport of lactoferrin into cerebrospinal fluid via plasma in young calves. J. Vet. Med. Sci. 65:957-964.

Tsuda, H., K. Sekine, K. Fujita, and M. Iigo. 2002. Cancer prevention by bovine lactoferrin and underlying mechanisms - A review of experimental and clinical studies. Biochem. Cell Biol. 80:131-136.

Uni, Z., G. Zaiger, and R. Reifen. 1998. Vitamin A deficiency induces morphometric changes and decreased functionality in chicken small intestine. Br. J. Nutr. 80:401-407.

Uni, Z., G. Zaiger, O. Gal-Garber, M. Pines, I. Rozenboim, and R. Reifen. 2000. Vitamin A deficiency interferes with proliferation and maturation of cells in the chicken small intestine. Br. Poult. Sci. 41:410-415.

Van Leeuwen, P., S. J. Oosting, J. M. V. M. Mouwen, and M. W. A. Verstegen. 2000. Effects of a lactoperoxidase system and lactoferrin, added to a milk replacer diet, on severity of diarrhea, intestinal morphology and microbiology of digesta and faeces in young calves. J. Anim. Physiol. A Anim. Nutr. 83:15-23.

van Merris, V., E. Meyer, K. De Wasch, and C. Burvenich. 2002. Simple quantification of endogenous retinoids in bovine serum by high-performance liquid chromatography - diode array detection. Anal. Chim. Acta 468:237-244.

Warden, R. A., M. J. Strazzari, P. R. Dunkley, and E. V. O'Loughlin. 1996. Vitamin A-deficient rats have only mild changes in jejunal structure and function. J. Nutr. 126:1817-1826. 
Weissmann, G. 1961. Alterations in connective tissue and intestine produced by hypervitaminosis A in Xenopus laevis. Nature 192:235-236.

Woodward, T. L., J. D. Turner, H. T. Hung, and X. Zhao. 1996. Inhibition of cellular proliferation and modulation of insulin-like growth factor binding proteins by retinoids in a bovine mammary epithelial cell line. J. Cell. Physiol. 167:488-499.

Yanai, T., C. Matsumoto, H. Takashima, K. Yoshida, H. Sakai, K. Isowa, T. Iwasaki, Y. Sato, and T. Masegi. 1996. Immunohistochemical demonstration of S-phase cells by anti-bromodeoxyuri- dine monoclonal antibody in cattle tissues. J. Comp. Pathol. 114:265-272.

Yuen, D. E., and A. F. Stratford. 2004. Vitamin A activation of transforming growth factor $\beta_{1}$ enhances porcine ileum wound healing in vitro. Pediatr. Res. 55:1-5.

Zanker, I. A., H. M. Hammon, and J. W. Blum. 2000. $\beta$-carotene, retinol and $\alpha$-tocopherol status in calves fed the first colostrum at $0-2,6-7,12-13$ or $24-25$ hours after birth. Int. J. Vitam. Nutr. Res. 70:305-310.

Zile, M., E. C. Bunge, and H. F. Deluca. 1981. DNA labeling of rat epithelial tissue in vitamin A deficiency. J. Nutr. 111:777-788. 